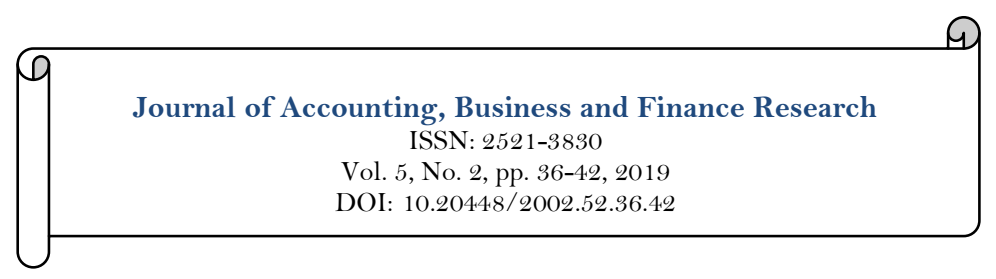

$\checkmark$ updates

\title{
A Literature Review of Research on China's Monetary Policy and Debt Leverage
}

\author{
Jiaming $\operatorname{Lin}^{1}$ \\ 'Doctoral student. School of Economics, Central University of Finance and Economics, Beijing, China \\ Email:linjiaming1107@163.com
}

\begin{tabular}{|c|c|}
\hline Abstract & \\
\hline $\begin{array}{l}\text { One of the problems of China's economic transformation is the high debt } \\
\text { leverage, the call for deleveraging has become one of the hottest issues in } \\
\text { recent years. The existing researches have discussed extensively the level and } \\
\text { structure of China's debt leverage, as well as its impact on financial stability. } \\
\text { This paper mainly reviews the impact of monetary policy and tools on the } \\
\text { debt leverage, in order to research the debate of "Loosing deleverage" or } \\
\text { "tightening deleverage". We think that the structural problems of debt } \\
\text { leverage should be adjusted by structural monetary policy. Monetary policy } \\
\text { regulation cannot be a decisive factor in reducing high debt leverage. } \\
\text { Clarifying the influence mechanism and path of monetary policy regulation, } \\
\text { we can prescribe the right medicine. In the process of steadily deleveraging, } \\
\text { we should also pay attention to the sustainability of debt. Therefore, using } \\
\text { monetary tools to steadily deleverage is not a loose or tight policy choice, but } \\
\text { an orderly guidance of all macroeconomic sectors on the basis of maintaining } \\
\text { a sound monetary policy. }\end{array}$ & $\begin{array}{l}\text { Keywords: } \\
\text { Debt leverage } \\
\text { Monetary policy } \\
\text { Deleverage } \\
\text { Licensed: } \\
\text { This work is licensed under a } \\
\text { Creative Commons Attribution } 4.0 \\
\text { License. } \\
\text { Publisher: } \\
\text { Scientific Publishing Institute }\end{array}$ \\
\hline
\end{tabular}

Funding: This study received no specific financial support.

Competing Interests: The author declares that there are no conflicts of interests regarding the publication of this paper.

\section{Introduction}

According to BIS statistics, China's debt leverage ratio was $255.7 \%$ by the December 2017, an increase of $114.4 \%$ over 2008. Among them, the non-financial corporate sector's leverage ratio is as high as $156.9 \%$, and the problem of excessive debt leverage is causing widespread concern in all sectors of society. According to the calculation of the leverage ratio of China's general-purpose government departments considering the implicit debt of local governments in 2016 is $62.2 \%$, which has exceeded the EU warning line standards. Zombie enterprises and inefficient investment projects have crowded out financial resources, and structural contradictions have become prominent. In December 2015, the Central Economic Work Conference proposed a supply-side reform strategy. For the first time, "deleveraging" was the key task in the future work, emphasizing that in the process of economic development, we should focus on improving the debt structure, gradually reducing leverage, and preventing financial risks. In August 2018, the National Development and Reform Commission, together with the People's Bank of China, the Ministry of Finance, the Banking Regulatory Commission, and the State-owned Assets Supervision and Administration Commission jointly issued a document stressing the reduction of corporate leverage, and on the basis of establishing and improving corporate debt risk prevention and control, improving supporting policies and promoting deleveraging. The high level of attention on debt leverage at the national level is sufficient to reflect the important impact of this issue on the quality of China's economic development.

We are concerned about the reasons of China's rapidly rising debt leverage. Is there a direct relationship between the increase in the supply of money and the formation of high debt leverage? These are not only academic issues, but also important policy issues. 
To understand the issue of monetary policy and China's high debt leverage, we should first understand the relationship between the two things. In recent years, scholars have been arguing about whether to "loose and deleverage" or "tighten and deleverage". Some scholars believe that monetary policy has a reverse impact on leverage by regulating the money supply (Liu \& Zhang, 2016; Lius, 2018; Song, 2014) others think that the increasing money supply can promote economic growth. At the same time, it will lead to a sustained and rapid increase in leverage (Wang \& Du, 2018). However, there are not many literatures on monetary policy and debt leverage. For these different perspectives, this paper conducts a systematic inductive analysis and lays the foundation for subsequent research on monetary policy and leverage.

On the basis of clarifying the mechanism of monetary policy and debt leverage, this paper discusses the extension between monetary policy and China's debt leverage. There are two important characteristics of the problem of excessively high leverage, which deserves attention: firstly, structural factors. The debt leverage ratio of non-financial enterprises has contributed the most to the rise of China's macro leverage. Therefore, when studying the performance of monetary policy on debt leverage, we should pay more attention to the impact of monetary policy on the structural structure of debts in various macroeconomic sectors. Secondly, debt sustainability issues. From the perspective of prevention of systemic financial risks, whether the debt leverage ratio of the macroeconomic sector is sustainable is also an important issue worthy of attention when studying the relationship between the two (2017 China Financial Forum). we believe that understanding the characteristics of monetary policy and China's macro leverage is not only from the indicator itself, but also by explaining the complex mechanism of monetary policy on the complex structure of China's macroeconomic sector debt structure.

\section{The Theoretical Basis of Debt Leverage and Monetary Policy}

2.1. Economic Explanation of Debt Leverage Ratio

2.1.1. Definition of Debt Leverage

From the micro perspective, the leverage ratio reflects the ratio of borrowed capital to private capital, and the leverage ratio is higher, indicating that the borrowed capital is much more than its own capital. The macro perspective, the total debt leverage is usually used to measure the country's macro leverage, and it is also convenient for horizontal international comparisons (People's Bank of China Leverage Research Group, 2014) also used the ratio of debt to GDP as a measure of leverage. The difference between the above is that "debt" is the total debt that is used by each department of a country. Other scholars define M2/GDP to measure, the logic of this definition is that when monetary policy is loose, $\mathrm{M} 2$ growth is usually faster, which can reflect the social financing needs (Song, 2014). Although the definitions of the above three indicators are slightly different, the trend of debt leverage is logically consistent (Liu \& Zhang, 2016). To maintain comparability and ease of calculation, we use the definition of debt/GDP to explain debt leverage.

\subsubsection{Structural Decomposition of Debt Leverage}

No matter which measurement method is used, the fact that China's debt leverage ratio continues to rise is an indisputable fact. In order to clearly identify the reasons for the rising leverage ratio, some scholars (Huang, 2013; Ma, Dong, \& Shi, 2016) have decomposed leverage ratios on the basis of macroeconomic sectors (including financial enterprises, non-financial corporate sectors, central government, local governments, residents), the results show that China's high macro debt leverage is mainly contributed by the non-financial corporate sector and local government debt. At the same time, according to the "2017 China Leverage Process Report", China's high leverage ratio is mainly concentrated in non-financial enterprises, especially in heavy chemical industries and state-owned enterprises.

\subsubsection{Debt Sustainability}

Based on the complex linkage mechanism of the causes of debt leverage in various sectors, solving the problem of high debt leverage of non-financial corporate departments and local government departments need to be researched from multiple angles. In the process of steadily reducing leverage, we must not only recognize structural problems, but the issue of debt sustainability.

Debt sustainability refers to the state that the borrower has the ability to repay debts without significant adjustments in future balance sheets. In short, debt sustainability is the ability to maintain debt balance without credit Default risk, maintaining debt_ financing__ebt repayment_—a state of balance. Specifically, we will care about maintaining this balance. What aspects should monetary policy start in the process of regulation? Simply from the perspective of micro-aggregation: when the return on assets or the rate of return on investment is greater than the cost of financing, individuals in economic activities tend to operate in debt, at this time not only profitable, but also maintain debt balance; when the return on assets When it is less than the financing cost, the debt management will face a crisis that cannot be used. Therefore, monetary policy regulation wants to "steadily deleveraging", not only needs to take structural measures, but also maintain debt sustainability, from the perspective of being able to adjust the return on investment and financing costs, through the adjustment of monetary policy makes the non-financial corporate sector not subject to serious default risk. 


\subsection{Monetary Policy Environment}

From the fact that the leverage ratio of the non-financial enterprise sector is relatively high, we can speculate that this aspect reflects the supply and demand of financial market funds under the control of monetary policy, and on the other hand, it also reflects the issue of enterprise investment and financing.

In theory, monetary policy can be divided into aggregate and structural monetary policy. The total monetary policy, also known as the general monetary policy, is a monetary policy in the general sense that uses the deposit reserve ratio, the rediscount rate, and the open market business to regulate the monetary funds. The total monetary policy is for the funds. Adjustments usually use M2 as an intermediate target to influence the interest rate price by adjusting the money supply. The structural monetary policy is the monetary policy adopted by the western advanced economies to adjust the liquidity fluctuation of financial markets after the subprime mortgage crisis in 2007 (Lu \& Deng, 2015). At the beginning of 2013, China has also established structured currencies including targeted RRR, targeted refinancing, directional adjustment of loan-to-deposit ratio and open market short-term liquidity adjustment (SLO), standing loan facility (SLF) and mortgage replenishment loan (PSL). The use of SLO and SLF can reduce the financing costs of SMEs (Liuu, 2017; Wangg, 2018) can adjust the liquidity of financial institutions, clear credit channels, and optimize the upgrading of industrial economic structure (Peng \& Fang, 2016) At the same time, structured monetary policy tools can encourage banks to invest funds into the real economy and reduce the financing costs of the corporate sector through the "incentive compatibility" mechanism (Deng, 2015).

From the regulation of monetary policy, it is divided into the regulation of monetary quantity and the regulation of monetary price. The regulation of monetary quantity is mainly used at the macro level. Price distortion is easy to occur in the process of transmission. Currency price regulation is mainly the selfregulation of microeconomic entities based on macro signals. This regulation requires financial institutions to have strong pricing power, and the micro-subjects must have sufficient interest rate sensitivity (Xu, 2018). From the international experiences, Western developed economies mainly adopt interest rate-based price regulation, while emerging developing economies mainly rely on quantitative regulation (X. Zhou, 2004).

According to the reality of China's economic development, the policy of adjusting the market interest rate by the total monetary policy cannot effectively adjust the structural problems, nor fully apply the needs of economic structural transformation, and the directional monetary price adjustment under the structural monetary policy maybe a more effective means (Xu, 2018). The description of the monetary policy environment provides a new perspective for understanding the issue of debt leverage: from the perspective of the cause, it is necessary to "prescribe the right medicine" for different economic problems. The application of different monetary policy tools will have different effects on the debt behaviour of various departments. The total policy may have little effect on the resolution of structural problems.

\section{Monetary Policy and High Debt Leverage}

From the perspective of the debt leverage indicator itself, the reason for the formation of high debt leverage comes from the relative value of debt and GDP. What causes the total amount of debt to be greater than the total amount of the GDP?

With the growing appeal of deleverage, scholars are increasingly studying the reasons for the formation of high debt leverage. The mainstream views can be summarized into the following three types: Firstly, the credit expansion caused by the expansion of the base currency. When the monetary environment is loose, the enthusiasm for investment in the corporate sector is high, leading to an increase in the scale of credit. Secondly, debt financing accounts for a relatively high proportion of social financing structures. On the one hand, the level of financial development in the developing countries is not high and the legal environment is not complete, the entities tend to use debt financing, which leads to an increase in the proportion of debt; on the other hand, because in the countries dominated by the banking system, the financial sectors also tend to lend funds to companies with good credit qualifications and mortgage guarantees, but these companies may have not high asset yields ,to obtain stable income and increase the debt scale of non-financial corporate sectors. Thirdly, the imbalanced structure of resource allocation among macroeconomic sectors, commonly referred to as "soft budget constraints", is mainly manifested in the fact that corporate sector has a corporate debt leverage ratio or higher government debt in government departments, but state-owned enterprises and local governments. The existence of "hidden guarantees" has also increased the scale of financing in the financial sector.

Some scholars think that the formation of high debt leverage is closely related to the economic cycle. Liul (2018) from the perspective of macroeconomic stability, found that the rise of macro leverage is in accordance with the natural law of economic development. The impact of monetary policy is actually the trend of macro leverage around its volatility. Excessive tightening of monetary policy will lead to more High leverage. Xiao (2010) found that debt leverage has obvious periodic characteristics, and this change is mainly consistent with the expansion and contraction of the balance sheet. Fang (2015) discussed the current economic cycle and the debt cycle stage, and believes that if the high leverage of non-financial companies continues to rise, it may touch the moment of invention. On the basis of Juglar's research, Ji, Yan, and Li (2017) found the phenomenon that the micro-latency ratio and the macro-latency ratio are inconsistent with the economic cycle after the 
innovation of technological innovation, such as micro-leverage rate and economic cycle. Fluctuations are consistent, and macro leverage may deviate during the expansion and recession due to lag.

In general, the rise in debt leverage is inseparable from the adjustment of monetary policy and the allocation of financial resources. Specifically, when studying the impact of monetary policy on debt leverage, the current mainstream analysis method is DSGE (Chen \& Liu, 2017; Hu, 2014; J. Zhou, Wang, \& Han, 2018) and the balance sheet method (Liul, 2018; Xiao, 2010). In the use of the DSGE model, scholars mostly discuss the impact of monetary policy on major economic variables by establishing a multi-sector macroeconomic model; the Balance Sheet Approach analysis method can link the assets and liabilities of various macroeconomic sectors. The relationship can clearly reveal the interaction between various departments. It is often used in the analysis of systemic risk conduction analysis. In addition, another advantage of applying asset-liability analysis is that the high level of China's macro debt leverage is due to the rise of non-financial corporate debt. And corporate debt is mostly used for investment, and assets will be formed in the future, so it is more logical to know the debt of assets $(\mathrm{Li}, 2016)$.

Combining the above reasons and analysis methods, this paper attempts to use the balance sheet method analysis and economic cycle theory to research the high debt leverage ratio of non-financial enterprise departments to explain the impact path of monetary policy and its relationship with other departments. Starting from the non-financial enterprise sector, the high debt leverage ratio means that the enterprise sector's stock liabilities are greater than the self-owned assets, which is reflected in the increase in the total amount of corporate sector debt financing (including equity and creditor's rights). Accordingly, the increase in corporate sector debt can be reflected. The increase in assets of the department, the increase in credit assets of the financial sector, the increase in investment financial assets such as equity and credits held by the resident sector, and the increase in assets of government departments in equity and taxation. In times of economic prosperity, companies will tend to increase their debts and take the initiative to expand the scale of financing and increase the rate of return on investment, which is reflected in the expansion of balance sheets and the increase in leverage. In countries dominated by the banking system, entities actually choose debt-based financial instruments for financing (Porta, Lopez-de-Silanes, Shleifer, \& Vishny, 1998). The financing interest rate actually becomes an important factor affecting the expansion of assets and liabilities of enterprises, and the financing rate as an important tool for the central bank's monetary policy adjustment, it is closely related to the monetary authority's balance sheet. When the monetary authorities' interest rate adjustment is transmitted to the financial sector, it will affect its deposit and loan interest rates and the scale of credit expansion, which in turn will affect the scale of credit of corporate sector (Liu, Niu, \& Yang, 2009). When the supply and demand of market funds is tight, and the balance sheet of the corporate sector deteriorates, the quality of credit assets in the financial sector will inevitably decline.

The income of government departments (mainly taxation) will decrease, the income of household investment in the residential sector will decline, and the income of individual labour will decrease, which will lead to debt repayment. A series of interlocking issues, such as declining capacity, declining consumption, and deterioration of personal consumption credit assets in the financial sector. From the perspective of balance sheet, corporate debt management is understandable, and it is only natural that the formation of high debt leverage in non-financial corporate sectors is not terrible. What is really terrible is that the assets (or future earnings) of non-financial corporate sectors are insufficient to support their excessive debt. At the time, the parties involved in lending in the entire economic chain need to pay the price. The essence of deleveraging should be the return to the source, and the parties that regulate high debts should fully invest and speculate. The difference is that the debt is matched with its own production and operation capabilities. In addition, from the perspective of balance sheet, when using the policy adjustment tool to control the debt leverage of nonfinancial enterprises, it is also possible to explain the sustainability of debt by discussing its solvency, so as to achieve the control of the total debt scale. Avoid systemic default risks.

The above analysis is only a simple framework to illustrate the complexity of the causes of monetary policy on debt leverage. Failure to comprehensively explain the changes in debt leverage of the financial sector, non-financial corporate sector, government sector, and residential sector under the adjustment of monetary policy are the shortcomings of this paper.

\section{Monetary Policy and Deleveraging}

Based on the above-mentioned monetary policy's influence mechanism on the formation of high debt leverage, monetary policy regulation can be one of the measures to deleverage, but studies have been debated whether "loose deleverage" or "tightening leverage".

\subsection{Different Interpretations of "Loose Deleverage" or "Tightening Leverage"}

One explanation is that the impact of loose monetary policy on debt leverage is positive. Bauer and Granziera (2017) explored the impact of monetary policy shocks on leverage based on data from developed countries. Tight monetary policy will lead to an increase in leverage in the short term. In the long run, rising capital costs will weaken the willingness to borrow and promote Leverage has fallen. Wang and Du (2018) discussed the impact of money supply and interest rate shock on leverage ratio from the transmission 
mechanism of monetary policy and economic growth: the increase in money supply will lead to the growth of output while also bringing leverage. The rapid increase in interest rates can suppress the increase in leverage in the short term, and in the long run it will cause the leverage to rise again. At the same time, the money supply has a greater impact on the change in leverage than the interest rate. Another explanation is that the impact of loose monetary policy on debt leverage is negative. Song (2014) found the impact of monetary policy on M2/GDP from the perspective of the periodic cycle of money circulation, summed up the phenomenon of "the less and more money", that is, when the active monetary policy is implemented to make M2 rise, the increase of GDP may be more fast, making M2/GDP decline; when tightening monetary policy is implemented, GDP may fall faster than M2, making M2/GDP rise instead. Liu and Zhang (2016) found the relationship between money supply and leverage ratio through the revised DSGE model. The study found that under the financial accelerator effect, the rise of $\mathrm{M} 2$ is more likely to cause asset prices (such as house prices) to rise rapidly. The expansion of investment and consumption channels has contributed to GDP, which in turn has led to a decline in leverage. From the point of debt efficiency, some scholars believe that tightening and deleveraging may bring debt liquidity risk, which will eventually lead to "debt-deflation" risks (Jii, Li, \& Yang, 2018). From the argument about "loose" or "tightening" to reduce leverage, the first view is easier to understand. The loose monetary policy is transmitted through various intermediate indicators of currency (such as interest rate, exchange rate, etc.), which will stimulate all departments to obtain High-yield through more debt; the second view is from the debt side, that is, the impact of bank deposits on the macroeconomic leverage due to the derivation of credit. Combined with the monetary policy environment of China in recent years, we can confirm the existence of the "leverage rate paradox". Therefore, whether it is a loose or tight monetary policy, the effect of adjusting the nominal monetary aggregate on reducing the debt leverage ratio may be limited.

In addition, some scholars believe that the impact of monetary policy regulation on debt leverage is minimal. Yang and Gao (2016) pointed out that loose monetary policy may bring about asset bubbles, offset the role of expansionary monetary policy in promoting the real economy, and the implementation of policies cannot promote the growth of the economy and the de-leveraging of the denominator. $\mathrm{Hu}(2014)$ puts "lower leverage" and "stable growth" as the policy objectives to introduce the optimal decision-making problem of monetary authorities. The research found that the effect of regulating the growth of money supply to reduce the leverage ratio is not ideal, and the effect is unstable and vulnerable; Chen and Liu (2017) used the TVPVAR model to study the dynamic mechanism of macro leverage, economic growth and monetary policy, found that the tightening monetary policy has macro leverage. The rate has both positive and negative effects. On the one hand, it will cause a slight increase in the macro leverage ratio, which is not conducive to "lowering leverage". On the other hand, it will greatly reduce the fluctuation of macro leverage and restrain its excessive rise, which is conducive to "stable leverage". Although the tightening monetary policy can not reduce the debt leverage ratio, it can reduce the speed of debt leverage.

Although there is unified conclusion on the issue of leverage reduction, it provides research ideas for follow-up research: the adjustment of debt leverage ratio by monetary policy cannot be measured simply by the leverage ratio itself or the influence of monetary policy on economic indicators. The complexity of the monetary policy in the macroeconomic environment, especially between the various sectors of the economy, should be taken into account, and it will be affected by many external factors. "loosing" or "tightening" monetary policy is only one of the exogenous conditions in the study of this issue, and it cannot be a decisive factor.

\section{2. "Steady Growth" and "Lower Leverage"}

Although monetary policy cannot be "one size fits all" in solving the problem of deleveraging, we expect to study the monetary policy to coordinate the balance between "steady growth" and "lower leverage".

Schularick, Alan, and Taylor (2010) found that a central bank should pay close attention to changes in the credit scale of various economic sectors and should pass the total amount of credit. Control regulates leverage. Devereux and Yetman (2010) found that the central bank can go against the trend and use a monetary policy such as raising interest rates to transfer to various economic sectors when the leverage ratio is high, thus stabilizing the increase in leverage. Benignop, Eggertsson, and Romei (2014) argue that the optimal monetary policy should raise the level of natural interest rates to create an accelerated "deleveraging" economic environment and ultimately reduce the duration of the economic crisis. Foreign scholars are based on tightening interest rates to achieve policy effects. The basis for effective is the high marketization level and the smooth flow of interest rate transmission. This difference determines Western model cannot be fully emulated when we use monetary policy tools to reduce leverage. Therefore, when domestic scholars discuss this issue, they often include a variety of factors for discussion. Shao, Chen, and Yang (2018) explored the impact of monetary policy and fiscal policy on the leverage ratio of various macroeconomic sectors by establishing a five-sector stock-flow model. It found that tightening monetary policy would increase the leverage of the government and the corporate sector, would reduce the leverage of the resident sector. Tax cuts and ways to improve internal cash flow can better balance de-leverage and steady growth. Luoo and Chen (2018) under the condition of high leverage, monetary policy has a greater impact on economic variables such as output and 
investment. The adjustment of monetary policy should be stable in the process of deleveraging. In addition, when a single policy cannot solve the dilemma of "stable growth" and "lower leverage", some scholars have proposed the idea of "turning leverage" among the national economic departments. Zhou, Wang and Han (2018) under the impact of interest rate and real estate demand, when the leverage was transferred from the enterprise to the residents, the total social welfare level was the largest. Gou, Yuan, and Qi (2016). explained the perspective of debt leverage and systemic risk accumulation, and found that the non-financial corporate sector debts are appropriately transferred to the residential sector or government departments, which can enhance the macroeconomic level of resisting systemic risks. Ji et al. (2017) also think that the debt leverage of the national economic sector can be transferred, but the transfer of leverage should be determined by the market. The regulation of macroeconomic policies should be neutral.

Combined with the US practice of deleveraging after the subprime mortgage crisis and Japan's collapse of the real estate bubble there are several methods for reducing leverage, but none of them can be immediately seen, and no one is without cost $(\mathrm{Li}, 2016)$. Looking at the rapid growth of China's economy under the "debtdriven" trend in the past decade, in the process of deleveraging, we must not only find ways to control the scale of debts of various departments, but also strive to achieve economic growth.

\section{Review and Conclusion}

From the implementation of the policy requirements of deleveraging, we believe that the analysis of monetary policy and debt leverage cannot be considered only from the changing of leverage ratio, but also the systematic analysis of the structural problems of the non-financial corporate sector relative to the high leverage ratio of other economic sectors. The performance of debt leverage is ultimately derived from continuity, we can take measures to form a preventing-controlling means, so as to ensure the smooth operation of the macro economy. At the same time, the economic sector with excessive debt leverage should also pay more attention to the contagion of systemic financial risks.

1. Fully understanding the structural problems of China's debt leverage and pushing the implementation of structural monetary policy. Non-financial corporate debt and local government debt problems are key sectors for the formation of high debt leverage. The adjustment of this debt structure requires structural policies that are compatible with the economic characteristics of the sector. Solely relying on monetary policy to achieve the dual goals of "deleveraging" and "stable growth" is a huge challenge.

2. Unblocking the transmission mechanism of monetary policy and improve the effectiveness of monetary policy regulation. Although monetary policy is only one of the policy measures for the structural adjustment of debt leverage, it is still important to unblock the transmission mechanism of monetary policy. In terms of interest rate channels, the central bank can adjust the monetary policy orientation, improve policy transparency, strengthen information communication, and encourage financial institutions to bid to determine the direction quota and price, so that interest rates can be smoothly transmitted to the real economy.

3. Continue to maintain a sound monetary policy and promote deleveraging in the macroeconomic sector. The central bank can use monetary policy tools such as targeted RRR to provide support for debt-to-equity swaps, continuously expand financing channels, and encourage entities to use equity-based financial instruments. From the perspective of credit default and debt sustainability, developing capital markets to transform the financing model of entity enterprises can reduce corporate debt leverage and maintain the sustainable and healthy development of the real economy.

4. Exploring the relationship between debt leverage among various macroeconomic sectors. As mentioned above, under the analytical framework of the macro balance sheet, the linkage effect of various macroeconomic sectors is obvious. From a theoretical perspective, when studying the impact of monetary policy on debt leverage in various sectors of the macro economy, we can consider establishing a multi-sectoral macro-balance sheet and systematically explain the relationship between monetary policy and debt leverage.

\section{References}

Bauer, G. H., \& Granziera, E. (2017). Monetary policy, private debt and financial stability risks. International Journal of Central Banking, 13, 337-373.

Benignop, P., Eggertsson, G. B., \& Romei, F. (2014). Dynamic debt deleveraging and optimal monetary policy. NBER Working Paper, No 20556.

Chen, D., \& Liu, J. (2017). Understand the mode of China's monetary policy regulation: "Stable leverage" or "down leverage"? —_an empirical study based on TVP-VAR model. Journal of Xi'an Jiaotong University (Social Science Edition), 11, 1-8.

Deng, X. (2015). The application of structural monetary policy tools: Practice and enlightenment in developed countries. Southern Finance, 1, 26-34.

Devereux, M. B., \& Yetman, J. (2010). Financial deleveraging and the international transmission of shocks. The International Financial Crisis and Policy Challenges in Asia and the Pacific, 52, 274-298.

Fang, X. (2015). Economic cycle, debt cycle and equilibrium. China Finance, 17, 67-68.

Gou, W., Yuan, Y., \& Qi, X. (2016). Debt leverage and systemic risk contagion mechanism—analysis based on CCA model. Financial Research, 3, 74-89. 
Hu, Z. (2014). The optimal policy setting of monetary authorities under the dual objectives of "steady growth" and "control lever". Economic Research, 12, 60-71.

Huang, Z. (2013). Differences in leverage ratios among various sectors of China's national economy and policy recommendations. International Finance, 1, 51-53.

Ji, M., Yan, B., \& Li, H. (2017). Leverage structure, level and financial stability: Theoretical analysis framework and China experience. Financial Research, 2, 11-25.

Jii, M., Li, H., \& Yang, X. (2018). Leverage level, economic structure transformation and "debt-deflation" risk. Macroeconomic Research, 1, 15-27.

Li, Y. (2016). Comprehensive policy "de-leveraging. China Economic Report, 10, 83-85.

Liu, X., Niu, M., \& Yang, P. (2009). Analysis of Chinese residents' balance sheet. Financial Research, 10, 107-117.

Liu, X., \& Zhang, J. (2016). The paradox of China's leverage ratio—_also on the true dilemma of "steady growth" and "lowering leverage" in monetary policy? Finance and Trade Economics, 8, 5-19.

Liul, Y. (2018). Research on the influence of monetary policy on the macro-length ratio gap. Journal of Finance and Economics, 6, 46-54.

Lius, Y. (2018). Research on the influence of monetary policy on the macro-length ratio gap. Journal of Finance and Economics, 6, 46-54.

Liuu, W. (2017). Can monetary policy assume responsibility for restructuring? Learning and Practice, 10, 49-56.

Lu, L., \& Deng, X. (2015). International comparison and enlightenment of structural monetary policy tools. World Economic Research, 6, 3-11.

Luoo, Y., \& Chen, B. (2018). The impact of monetary policy under high and low leverage and the stability of monetary policy in the process of de-leverage — test of financial accelerator effect based on DSGE model. Finance and Trade Research, 8, 62-74.

Ma, J., Dong, X., \& Shi, H. (2016). China's leverage ratio and systemic financial risk prevention. Finance and Trade Economy, 1 .

Peng, Y., \& Fang, Y. (2016). Structural monetary policy, industrial structure upgrade and economic stability. Economic Research Journal, 7, 29-42.

People's Bank of China Leverage Research Group. (2014). China's economic leverage level assessment and potential risk research. Financial Supervision Research, 5, 23-38.

Porta, R. L., Lopez-de-Silanes, F., Shleifer, A., \& Vishny, R. W. (1998). Law and finance. Journal of Political Economy, 106(6), 1113-1155.

Schularick, M., Alan, M., \& Taylor. (2010). Credit booms gone bust: Monetary policy, leverage cycles, and financial crisis: 1870-2008. NBER Working Paper, No 15512.

Shao, Y., Chen, D., \& Yang, X. (2018). Rebalancing: De-leverage and steady growth--analysis based on the stock-flow consistent model. Financial Research, 10, 4-23.

Song, G. (2014). The interest rate is the car. The exchange rate is the horse (pp. 33-35). Beijing: Peking University Press.

Wang, A., \& Du, Q. (2018). Steady growth and leverage: How to choose the central bank's monetary policy under the policy paradox. Journal of Tianjin University of Finance and Economics, 3, 27-36.

Wangg, W. (2018). Structural monetary policy, corporate financing costs and investment scale. Financial Theory and Practice, 9, 17-20

Xiao, Q. (2010). Liquidity, leverage and financial stability. Financial Development Research, 9, 9-14.

$\mathrm{Xu}, \mathrm{Z}$. (2018). The transformation of China's currency regulation and control mode in the stage of high-quality economic development. Working Paper of the People's Bank of China, 3, 1-19.

Yang, J., \& Gao, H. (2016). International comparison and path selection of industry "addition and subtraction leverage. Journal of Shanxi University Philosophy and Social Sciences Edition, 6, 61-66.

Zhou, J., Wang, Y., \& Han, X. (2018). De-leverage, leverage and monetary policy transmission— — based on the research of new Keynes dynamic general equilibrium. International Finance Research, 5, 24-34.

Zhou, X. (2004). Several issues that need to be paid attention to in the current improvement of the monetary policy transmission mechanism. Paper presented at the Senior Seminar on China's Monetary Policy Transmission Mechanism. 